\title{
Duygusal Zekâ ve İş Performansı Arasındaki İlişkinin Turist Rehberleri Açısından Değerlendirilmesi ${ }^{1-2}$
}

\author{
Evaluation of the Relationship Between Emotional Intelligence and Job Performance in terms of \\ Tourist Guides
}

\section{Dilara DENIZ* Hacer ARSLAN KALAY**}

\begin{abstract}
*Van Yüzüncü Yıl Üniversitesi, Sosyal Bilimler Enstitüsü, Van, Türkiye.

** Doç. Dr., Van Yüzüncü Yıl Üniversitesi, Turizm Fakültesi, Rekreasyon Yönetimi Bölümü, Van, Türkiye.
\end{abstract}

\section{ORCID:}

D.D.: 0000-0003-2447-6655 (D)

H.A.K.: 0000-0002-4203-8352 (D)

Corresponding Author:

Dilara DENIZ

Email

dilara.z@hotmail.com

\section{Citation:}

Deniz, D. ve Arslan Kalay, H., (2020). Duygusal Zekâ ve İş Performansı Arasındaki İlişkinin Turist Rehberleri Açısından Değerlendirilmesi, Journal of Academic Tourism Studies, 1(1): 3045.

\section{Özet}

Bu çalışmanın amacl, turist rehberlerinin duygusal zekâ düzeyleri ile iş performansları arasında anlamlı bir ilişkinin olup olmadığının saptanması, duygusal zekâ ve iş performansı düzeylerinin belirlenmesi; duygusal zekâ boyutları ile iş performansı arasındaki ilişkinin belirlenmesi ve bu ilişkinin turist rehberleri açısından değerlendirilmesidir. Araştırmanın evrenini Doğu ve Güneydoğu Anadolu'daki turist rehberleri oluşturmaktadır. Bu iki bölgedeki iller Şanlıurfa Rehberler odası (ŞURO) ve Gaziantep Rehberler odasi (GARO) olmak üzere iki kurum olarak faaliyet göstermektedirler. İki odaya kayıtlı eylemli rehber sayısı ise 251'dir. Evren büyüklüğ̈̈ 251, örneklem büyüklüğü ise 152 olup 155 kişiye anket uygulanmıştır. Verilerin toplanmasında yüz yüze ve online anket tekniği kullanılmıştır. Çalışma sonucunda turist rehberlerinin yüksek duygusal zekaya sahip oldukları ve duygusal zeka ile iş performansı düzeyleri arasında anlamlı ve pozitif bir ilişki olduğu tespit edilmiştir.

Anahtar Kelimeler: Duygusal Zekâ, İş Performansı, Turist Rehberleri

\section{Abstract}

This study has been prepared to determine if there is a significant reltionship between Emotional Intelligence's dimensions and Job Performance in terms of tourist guides. And to determine the level of emotional intelligence and job performance of tourist guides. Population of the study is composed of tourist guides that working in east and wouth west regions. The number of population is 251, sample size is 152 and totaly 155 questionaries have been applied. Face to face and online techniques were used to data collection. Inconsequence of the study the level of EI and JP of tourist guides has been determined. In general tourist guides hvehigh EI so they give a good performance at work. There is a significant relationship between EI and JP.

Keywords: Emotional Intelligence, Job Performance, Tourist Guides

\footnotetext{
1 Bu çalışma, Dilara DENIZ'in, Van Yüzüncü Yıl Üniversitesi, Sosyal Bilimler Enstitüsü, Turizm İşletmeciliği Anabilim Dalı'ında kabul edilen yüksek lisans tezinden türetilmiştir.

${ }^{2}$ Bu çalışma, Van Yüzüncü Y1l Üniversitesi, BAP Birimi tarafından SYL-2018-6933 nolu proje kapsamında desteklenmiştir.
} 


\section{GİRIŞ}

Çalışma hayatının kuralları her geçen gün değişmektedir ve artık çeyrek asırdan beri yeni ölçütler kullanılmaktadır. Akıllı olmak, eğitimde ve uzmanlıkta yetkin olmak yetmemekte, kişinin kendini ve başkasını idare etmekte ne kadar başarılı olduğu daha çok önem arz etmektedir. Bu ölçüt, işe alınacakların, elden kaçırılmayacakların, terfi edilmesi gerekenlerin seçilmesi için daha fazla kullanılmaktadır.

Duygusal zeka, siyasetten TV programlarına, iş yaşamından özel hayata her alanda dolaylı veya direkt olarak önemi vurgulanan bir kavramdır. Dolayısıyla insan ilişkilerinin yüksek düzeyde olduğu ve yüz yüze ilişkinin söz konusu olduğu turizm sektöründe duygusal zekanın önem derecesinin değerlendirilmesi fikri bu konunun çalışılmasını cazip kılmıştır. Sektörde çalışanlar açısından duygusal zekanın varlığının çalışma biçimlerini etkilediği varsayımından yola çıkılarak, çalışanların işteki başarısını ifade eden iş performansı ile duygusal zeka arasındaki ilişkinin saptanması hedeflenmiştir. Turizm sektöründe kültür elçiliği gibi önemli bir rol üstlenen turist rehberleri destinasyon imajını yansıtmakta ve o yerin sevilme ve tercih edilmesi için bir neden sunmaktadırlar. Turistlere karşı iyi birer dinleyici, anlayan ve ağırlayıcı olarak onları memnun etmektedirler. Bu memnuniyetin sağlanabilmesi için ayrıca, turist rehberleri çalışma esnasında, lider, yol gösterici, ara bulucu, problem çözen, motive eden danışman gibi birçok rol üstlenmektedirler. Bu rollerin niteliği duygusal zeka ile ilişkilendirildiğinden bu çalışmanın konusunu turist rehberlerinin duygusal zekaları oluşturmaktadır.

\section{KURAMSAL ÇERÇEVE}

\section{Duygusal Zekâ}

Duygu; psikolojik yanıtları, algıyı ve bilinçli farkındalığı içeren birçok psikolojik alt sistemleri koordine eden içsel olaylardır Mayer ve Salovey (2000:267). Daniel Goleman (2014) duyguyu; his ve bu hisse özgü belirli düşünceler, psikolojik ve biyolojik haller ve bir dizi hareket eğilimi olarak tanımlamıştır.

Zeka kavramının geçmişi insanlık tarihi kadar eski olsa da (Davis, 2004:3) kavram üzerinde ortak bir tanım bulunmamaktadır (Gürsoy, 2005:75). W. Stern'e göre, zeka; düşünsel uyum yeteneği, Binet'e göre iyi akıl yürütme, iyi hüküm verme ve iyi eleştirel görüşe sahip olmak, Thorndike'a göre, iyi tepkide bulunma yeteneği, Wechsler'e göre, bireyin amaca uygun hareket etmesi, mantıklı tartışabilme gücüdür (Bal, 2007:7, Akın, 2010:5). Sternberg ise zekayı; çevreyi seçmek, onu biçimlendirmek ve ona uyum sağlamak için gerekli olan zihinsel yetenek olarak tanımlamıştır (Karmyshakova, 2006:67).

İngilizce karşılığ $\mathrm{EQ}$ “EmotionalQuotient" veya EI “EmotionalIntelligence” olan duygusal zeka kavramı (Genç, 2013:37); insanın kendisinin ve başkalarının hislerini ve duygularını izleme, bunlar arasında ayırım yapma ve bu bilgiyi kendi düşünce ve eylemlerinde kullanabilme, yararlanabilme yeteneği olarak tanımlanmaktadır (Majeski vd., 2017:136; Malhotra ve Kaur, 2018:122; Panddey ve Sharma, 2016:7; Pehlivan, 2015:28; Salovey vd., 2001:279). Bar-On (2006:1415) duygusal zekayı; kişilerin kendi duygularını anlamasını ve ifade etmesini, başkalarının duygularını anlamasını ve iyi ilişkiler kurmasını ve çevreden gelen günlük talep, değişim ve baskılara karşı başarılı bir şekilde baş edebilmesini sağlayan duygusal, sosyal yeterlilik ve beceri dizini olarak tanımlamıştır. Goleman (2014:62) duygusal zekayı; kişinin kendini harekete geçirebilme, aksiliklere rağmen yoluna devam edebilme, dürtüleri kontrol ederek tatmini erteleyebilme, ruh halini düzenleyebilme, sıkıntıların düşünmesine engel olmamasını sağlayabilme, kendini başkasının yerine koyabilme ve umut besleme olarak tanımlamıştır. Cooper ve Sawaf (2010:11) duygusal zekayı; duyguların gücünü ve hızlı algılayışını, insan enerjisi bilgisi, ilişkileri ve etkisinin bir kaynağı olarak duyumsama, anlama ve etkin bir biçimde kullanma yeteneği şeklinde tanımlamıştır. Huggins vd., (2016:28) ise duygusal zekayı; duyguyu algılama ve anlama yeteneği, duyguyu; düşünceyi kolaylaştırmaya entegre etme kabiliyeti olarak tanımlamışlardır. 
Duygusal zekanın bireyler tarafından duyguların algılanması, bütünleştirilmesi, anlaşılması ve faydalanılmasını kapsadığı yönündeki genel kabul görmüşlüğünün altında farklı modeller yatmaktadır. Bu modellerden dört tanesi öne çıkmaktadır (Ilgın, 2010:62). Bunlar; Mayer ve Salovey'in Yetenek Modeli (Duygularını Anlama, Başkalarının Duygularını Anlama, Duyguları Ayarlama ve Duyguları Kullanma), Bar-On'un Kişisel faktörler Modeli (Kişisel Beceriler, Kişiler Arası Beceriler, Uyum, Stresle Başa Çıkma, Genel Ruh Durumu (Kulualp ve Erol, 206:122), Cooper ve Sawaf'ın Dört Köşe Taşı Modeli(duygusal okuryazarlık, duygusal zindelik, duygusal derinlik, duygusal simya) (2010:63-70).Son olarak ise çalışmada da işlenen Goleman'ın Duygusal Yeterlilik Modelidir (Öz Bilinç, Öz Yönetim, Motivasyon, Empati, Sosyal Beceriler) (Sarangi vd., 2017:478).

Duygusal zekanın yüksek olması iş hayatında her anlamda ve özellikle kriz durumlarında mantıklı davranmayı, gerginlik yaşanınca yatıştırmayı, soğukkanlı olmayı, güveni ve saygıyı kazanabilmeyi sağlamaktadır. İşleri yürütebilmeyi, global perspektiften bakabilmeyi, teknik donanıma da sahip olmanın gerekliliğinin bilincinde olmayı, yaratıcı fikirleri yakalayabilmeyi, yararlı fikirleri de pratik eyleme dönüştürebilmeyi mümkün kılmaktadır (Goleman, 2000:44-45). Bu açıdan duygusal zekâ turist rehberleri için de oldukça önemlidir. Turist rehberinin üstlendiği rollerin birçoğu duygusal zekâ modellerinde belirtilen yeterlilikleri gerektiren rollerdir. Rehberlerin, elçi, kültür aracısı ve ara bulucu, aracı, lider, yol gösterici, danışman gibi rollerinin niteliği duygusal zekâ modellerinin yeterliliklerine bağlı olduğu görülmektedir. Dolayısıyla duygusal zekânın, kişinin başkalarının duygularını da anlayabilme kabiliyetini kapsaması ve bu doğrultuda turist rehberlerinin sahip oldukları duygu durumlarını anlaması onlara daha iyi bir hizmet sunma olanağ1 sağlayacaktır (Ayana, 2016:18). Hizmet sektöründe görev yapan turist rehberleri için, rakipler arasında rekabetin belirleyicisi olarak hizmet kalitesinin ön plana çıması duygusal zekânın önemini arttırmaktadır.

\section{İş Performansi}

Literatürde iş performansı ile ilgili en yaygın karşılaşılan tanım Rousseau ve McLean (1993) tarafından yapılan tanım olup "çalışanların aldıkları ücret karşılığında göstermeleri gereken gayret" olarak ifade edilmektedir (Başaran, 2016:31). Ahmad vd., (2016:98) iş performansının; örgütün amacına ve başarısına katkıda bulunan çalışanların tüm faaliyetlerini kapsadığını belirtmiştir. İş performansı; bir işin miktar, nitelik, zaman ve maliyet etkinliği dikkate alınarak yapılması ve işin gereklerine uyum kabiliyetinin, verimliliğinin, başarısının ve işine olan ahlaki yaklaşımının bütününü ifade etmektedir. Performans; belirlenen koşullara göre bir işin yerine getirilme düzeyi ya da çalışanın davranış biçimidir (Ertan, 2008:43; Gürkaya, 2017:13; Kılı̧̧ ve Tavacıoğlu, 2016:216; Uğur, 2017:4). Campbell iş performansını bireysel seviyeli bir değişken olarak tanımlar (Ameli vd., 2013:31).

İş performansı yönetim biliminde bireysel ve kurumsal olmak üzere iki boyutta ele alınmaktadır (Kurt, 2013:5). Bu araştırmada ele alınan bireysel iş performansını etkileyen birçok faktör bulunmaktadır. Bunları bireysel, yönetimsel ve çevresel faktörler olarak sinıflandırmak mümkündür (Meriçöz, 2015:43). Kişilerin bireysel amaçları, hisleri, gibi kişisel özellikleri iş performansını etkileyen bireysel faktörler arasında sayılabilmektedir. Başlıca faktörler ise sosyodemografik özellikler (yaş, dil, cinsiyet, medeni durum, eğitim düzeyi), psikolojik özellikler (alg1, tutum, talep, eğilimler), rekabet özellikleri (ilgi ve yetenek) gibi kişisel özelliklerden oluşmaktadır (Nadir, 2014:126 ve Sevim, 2015:72). Bireysel performans kişinin kendisiyle ilgili bir durum olsa da aslında yönetim anlayışına göre değişiklik göstermektedir. Bireysel iş performansına etki eden yönetimsel faktörler arasında yönetim tarzı, çalışma şekli, ücret, iletişim, takdir edilme duygusu, motivasyon, stres gibi etkenler sayllabilmektedir (Gökgöz, 2016:34; Nadir, 2014:121). Yönetimsel faktörler değerlendirildiğinde; yenilikçi, değişime açık, akılc1, ve çağdaş bir yönetim süreci hakim değil ise, çalışanların tek başına performans yükseltmeye yönelik çabaları ve eylemleri çok anlam ifade etmeyecektir (Karayel, 2016:51). İş performansını etkileyen çevresel faktörler ise; toplumsal (aile, kulüp, dernek), ekonomik (gelir dağılımı ve gelir düzeyi), siyasal (yasalar ve yönetmelikler) ve kültürel (eğitim, din gibi) faktörlerden oluşmaktadır (Sevim, 2015:72). Bunların yanı sıra iş performansını etkileyen bir diğer faktörün duygusal zeka olduğu iddia edilebilir. Çünkü Davis'e 
göre bilişsel zeka (IQ) ile iş performansı arasındaki bağı inceleyen araştırmalar, IQ'nun iş performansının en çok yüzde yirmi beşini etkilediğini ortaya koymuştur (2004:4). Dolayısıyla iş performansı ile zeka arasındaki yüzde seksenlik bağı etkileyen faktörün çoğunlukla duygusal zeka olduğu söylenebilmektedir.

İş performansı ile ilgili literatürde çeşitli modeller vardır. Ancak kullanım alanı en yaygın olanı 1993 yılında Borman ve Motowidlo (Borman, 1991; Borman ve Motowidlo, 1993) tarafından önerilen modeldir. Bu modele göre, iki tür çalışan davranışı ortaya konmaktadır. Bunlar görev ve bağlamsal performans davranışlarıdır (Özdemir, 2017:48). Görev iş performansı; kişinin işin gerektirdiği görevleri yerine ne kadar iyi yansıttığılyla ve bireysel yeterliliğiyle ilgilidir. Bağlamsal performans; çalışanın bir görevin tamamlanması için iş arkadaşlarına yardımcı olması, işin gerçekleşmesi için katkıda bulunmasıdır (Sevim, 2015:71). Rol içi iş performansı olarak da nitelendirilen görev performansı, çalışanın işin yapılması için görevleri ne derece taşıdığıyla ve açıkçası işin somut tarafıyla ilişkilidir. Görev performansı sorumluluğa, tecrübeye ve yeteneklere dayalıdır. Performans işin niteliğine göre değişebilmektedir ve kurallar nettir (Kızıldaş, 2017:3638). Bu boyut, işin niteliğine ve diğer çalışanlar arası iletişim, motivasyon gibi bileşenlerle ilgilidir ve bağlamsal performansta iş değişse de tutum aynıdır. Performans kişiliğe, kişiler arası iletişime, kişisel iradeye ve tamamen gönüllülüğe dayanmaktadır. Özellikle turizmin emek isteyen bir sektör olmasından dolayı turist rehberlerinin hizmet kalitesi oldukça önemlidir. Hizmeti en iyi şekilde sürdürmenin temel unsuru iyi iş performansının sergilenmesidir (Sevim, 2015:68). İş performansının niteliği doğrudan müşterilere yansımaktadır ve bu da rehberin performans algısını etkilemektedir (Doğan, 2014:25).

\section{Duygusal Zekâ ve İş Performansı İlişkisi}

Sektörlerde rekabetin büyümesi iş performansına ve performansı etkileyen unsurlara önem verilmesi gerektiği sonucunu ortaya çıkararak duygusal zekanın iş performansında önemli rol oynadığını göstermektedir (Pandey ve Sharma, 2016:8).Salovey ve Mayer'in duygusal zeka kavramindan bahsetmesinden bu yana, bu kavram işle ilgili olaylarla ilişkilendirilmektedir. Duygusal zeka iş performansını tayin etmede en az IQ kadar önemlidir (Laurance ve diğ., 2016:322). Singh ve Mhmood (2017:233)'a göre birçok araştırmacı duygusal zeka ile iş performansı arasında pozitif ilişki bulmuş olduklarına ve bu ilişkilere vurgu yapmışlardır. Duygusal zekanın bireysel ve örgütsel performanstaki rolü kantlanmıştır (Moon ve Hur, 2011:1088). Emelander (2013:52)'e göre her ne kadar duygusal zekanın öğrenilen bir yetenek olup olmadığı tartışma konusu olsa da, iş hayatındaki önemi ve etkisi kesin kanıtlanmıştır. Muchal ve Solkhe (2017:20) ‘a göre duygusal zeka ile işin hızı, genel iş performansı, işin kalitesi, şirketin varlığını yönetmek, denetimsiz çalışma yeteneği, başkalarını yönetmek ve planlama yeteneği arasında olumlu ilişkiye bulunmaktadir.

İş hayatında yaşanan yeni gelişmeler yeni süreçlerin oluşmasına yol açmaktadır. Bu süreçler, çalışanın duygularının farkında olmasını, kendini ifade etmesini, iletişim ve empati yeteneğini ön plana çıkarmaktadır. Gündoğan, iletişim ve iş birliği becerisi yüksek çalışanın görevini yerine getirmede başarılı olduğunu ifade etmektedir (2016:73). Bu yetenekler duygusal zekası yüksek kişilerde bulunmaktadır. Duygusal zeka, her sektörde olduğu gibi turizm sektöründe çalışan açısından yarar sağlamaktadır. Doğru iletişim sağlandığında ve müşterilerin istekleri yerine getirildiğinde başarı sağlanmaktadır. Başarının sağlaması müşteri memnuniyetiyle doğru orantılıdır. Bu alanda çalışma yapmış olan birçok araştırmacıya göre duygusal zekası yüksek çalışan iş hayatında da başarı ve mutluluğu sağlamaktadır.

Duygusal zeka iş performansını arttırmakta; bilişsel zekanın ötesinde; katkı sunan bir alternatif faktör olarak görülmektedir. Böylece duygusal zeka, profesyonel başarının yanı sıra kişinin genel olarak bireysel ve bilişsel kapasitesinin öngörü gücünün artmasına da yardımcı olmaktadır. Duygusal zekanın oldukça yararlı olmasının nedeni; genel yaşamda kişisel tatmin ve akıl sağlığı için gerekli olan ve iş yaşamında da birkaç motivasyonel, duygusal ve sosyal yetenekler içermesidir (Castillo ve Valle, 2017:685-686). Moon ve Hur (2011:1089) ise yüksek 
duygusal zekilerin değişen iş ortamına, iş şartları vb. durumlara daha iyi ayak uydurduklarını ve böylece tükenmişlik, depresyon gibi durumlara maruz kalmadıklarını belirtmektedirler.

Duygusal zeka, çalışanların ilkelerini, insan davranışlarını anlamaları için, yönetim tarzlarını, kişiler arası becerileri değerlendirebilmelerine bir yol sağladığı için, oldukça önemlidir. İşe alım ve işte kalabilmek, hizmet ve müşteri ilişkileri için de önemli olduğu için duygusal zeka, iş performansı üzerinde etkiye sahiptir (Gündoğan, 2016:73). Duygusal zeka çalışanların sahip olduğu duygusal yetilerini kullanmalarını sağladığı için bireysel iş performanslarının arttırılmasında etkilidir. Bu nedenle birçok araştırmacı (Goleman, Salovey ve Mayer, Sony, Mekoth), yüksek iş performansı için gerekli yetkinlikleri belirlemek için duygusal zeka ve iş performansı konusuyla ilgili çalışmalar yapmışlardır (Gündoğan, 2016:75).

Duygusal zeka boyutları açısından bu ilişkiye göre; kişinin duygularının farkında olması iş performansını olumlu etkilemektedir. Kendi gücünün farkında olan çalışan, karşılaştığı sorunlar karşısında kendini değersiz hissetmez. Duygusal zekası yüksek çalışan azimli, iç motivasyonu yüksek, iyimser, empatik düşünen, iletişim becerisine sahip bir kişidir ve dolayısıyla yüksek iş performansina sahiptir (Kara, 2015:58- 59).

Turizm sektöründe müşterileri anlamanın yolu insanı ve insan davranışlarının anlaşılmasından geçmektedir. Duygusal zekası yüksek çalışan; işbirlikçi, başkalarının duygularını da kendi duygularını yönettiği gibi kontrol edebilir, stresi yönetebilen, pozitif ve hayattan zevk alan sosyal ilişkileri iyi olan kişidir ve bunların sonucu olarak kendini başarılı hissetmektedir (Yüksel, 2006:70- 71). Duygusal zeka sosyal bir beceridir ve bu beceri çalışanın iş performansını etkilemektedir (Gürbüz ve Yüksel, 2008:178). Duygusal zeka günlük yaşam ile iş hayatındaki başarının sürdürülebilmesine yardımcı olmakta, iş hayatının kalitesini arttırmakta ve böylece iş performansını olumlu yönde etkilemektedir (Özcan vd., 2016:288- 289). Duygusal zeka sayesinde çalışan duygularını uygun şekilde ifade etmekte, yapıcı tepkilerle işlerini yoluna koymaya meyletmektedir. Duyguların uygun şekilde ifade edilmesi iş performansını, fiziksel sağlığı ve psikolojik huzuru da olumlu yönde etkilemektedir (Davis, 2004:96).

Duygusal zeka kişisel gelişime, yüksek mantaliteye, iyi duruşa sahip olmaya katkıda bulunmaktadır. Bu yüzden yüksek özbilinç, öz kontrol, duygusal değerlendirme, empati, duyguların kullanılması ve düzenlenmesi, iyi iş performansıyla ilişkilendirilmektedir (Castillo ve Valle, 2017:686). İş performansıyla olan güçlü ilişkisinin yanı sıra, duygusal zeka günlük yaşamın her alanında iyi bir performans sağlamaktadır (Keri ve diğ., 2017:136). Öz bilinç çalışanın ne zaman duygusal izlenimini değiştirmesi gerektiğini bilmesine yardımcı olabileceği gibi empati de çalışanın duygusal emeği ne zaman uygulayacağını bilmesini sağlamaktadır. Yüksek duygusal zekalı çalışan iş hayatının bir parçası olarak duygularını kullanmaya ve sergilemeye daha meyilli olmaktadır. Ayrıca duygusal emek gerektiren işler için duygusal zeka daha iyi bir belirleyicidir (Ernest vd., 2011:79). Duygusal zeka; çalışanın iş hayatında sosyal sermaye inşa etmesine ve insanların olumlu ilişkiler beslemesine yardımcı olarak iş performansına oldukça önemli katkı sunmaktadır (Grewal ve diğ., 2006:132). Duygusal zeka çalışanın işinde belirgin duygusal ipuçlarının varlığını fark etmesine izin vermekte ve yüksek duygusal zekaya sahip çalışan, iş deneyiminden kaynaklanan olumsuz duyguların farkında olur. Dolayısıyla bu farkındalık; meydana gelen olumsuz duyguların yararlı hale getirilmesi için ön koşuldur (Dong vd., 2001:1062). Sony ve Mekoth (2016:24) iş performansını; işteki riskli veya kötü davranışlardan ve görevi kötüye kullanmak, kişiler arası iyi ilişkiler sürdürme gibi değişkenlerden etkilenen bireysel performans fonksiyonu olarak tanımlaması da yine bahsedilen değişkenlerin duygusal zekayla ilişkisini ortaya koymaktadır. Duygusal zeka sayesinde iyi bir iş performansı sergilenerek başarılı bir iş hayatına da sahip olunabilmekte ve böylece işten kaynaklı stresten uzak sağlıklı birey olunabilmektedir (Lindebaum, 2013). 


\section{YÖNTEM}

\section{Araştırmanın Amacı ve Önemi}

Araştırmanın amacı, turist rehberlerinin duygusal zekâ düzeyleri ile iş performansları arasında anlamlı bir ilişkinin olup olmadı̆̆ının saptanması, duygusal zekâ ve iş performansı düzeylerinin belirlenmesi; duygusal zekâ boyutları ile iş performansı arasındaki ilişkinin belirlenmesi ve bu ilişkinin turist rehberleri açısından değerlendirilmesidir. Hizmet sektörünün önemli bir kısmını oluşturan turist rehberliğinde insan ağırlıklı ilişkilerin daha fazla olmasından dolayı duygusal zekâ seviyesi yüksek olan kişilerin çalışması büyük önem arz etmektedir. Bu durum özellikle turist rehberlerinin misafirlerle iletişimi sırasında oluşabilecek duygu çeşitlerini tanımlayabilmeleri açısından oldukça önemlidir. Dolayısıyla duygusal zekâ sayesinde turist rehberleri, bireysel ve sosyal becerilerini iş hayatına uygulamada daha yetenekli olmakta ve gösterdikleri çabalar iş performanslarına olumlu bir şekilde yansımaktadır.

\section{Araştırmanın Modeli ve Hipotezleri}

Bilimsel çalışmalarda amaca uygun olarak verilerin en ekonomik biçimde toplanması ve çözümlenmesine araştırma modeli denilmektedir (Karasar, 2008:76). Dolayısıyla bu çalışmada ilişkisel tarama modeli kullanılmıştır. İlişkisel tarama modeli, herhangi bir olgu çerçevesinde birbirleriyle muhtemel ilişkisi olduğu düşünülen değişkenlerin özelliklerini tasvir etmeyi içeren bir araştırma modelidir (Büyüköztürk, vd., 2010:17; Ulus vd., 2010:44). Araştırmada bağımsız değişken turist rehberlerinin duygusal zekâ düzeyleri ve bağımlı değişken ise rehberlerin iş performansları olarak belirlenmiştir.

Duygusal zeka ile iş performansı ilişkisine yönelik yapılan bir çok çalışma bulunmaktadır. Bunlardan bazılar1; Salovey vd. (2006), Castillo ve Valle (2017), Lindebaum (2013), Moon ve Hur (2011), Dong vd. (2014), Emelander (2013), Ernest vd. (2011), Sony ve Mekoth (2016), Singh ve Mahmood (2017), Muchal ve Solkhe (2017), Avunduk (2016), Gürbüz vd. (2008), Kılıç ve Tavacıŏ̆lı (2016), Ayana (2016). Bu çalışmalarda duygusal zekanın iş performansını doğru yönde etkilediği sonuçlarına ulaşılmıştır. Dolayısıyla araştırmanın amacına ulaşmak için bu çalışmaların incelenmesi neticesinde geliştirilen hipotezler aşağıda sunulmuştur;

- $\quad \mathbf{H}_{1}$ : Duygusal zekâ ve rehberlerin iş performansları arasında pozitif bir ilişki vardır.

- $\quad \mathbf{H}_{2}$ : Rehberlerin duygusal zekâsı iş performanslarını etkilemektedir.

\section{Araştırmanın Evreni ve Örneklemi}

Araştırmanın evrenini Doğu ve Güneydoğu Anadolu'da eylemli çalışan turist rehberleri oluşturmaktadır. Şanlıurfa ve Gaziantep turist rehberleri odalarından alınan listeye göre bu odalara kayıtlı toplamda 251 turist rehberi bulunmaktadır. Bu çalışmada evrendeki kişi sayısı dikkate alınarak tam sayıma ulaşılması hedeflenmiştir. Bu çalışmada örneklem büyüklügüünün hesaplanması için aşağıdaki örneklem hesaplama formülünden yararlanılmıştır.

\section{Veri Toplama Araçları}

$\mathrm{Bu}$ araştırmada verileri toplamak için yüz yüze anket tekniği kullanılmıştır. Araştırmada katılımcıların duygusal zekâ düzeylerini ölçmek amacıyla yer verilen duygusal zekâ ölçeği kullanılmıştır. Söz konusu ölçek Mayer, ve diğ.,(2000), Goleman (2000)'ın duygusal zekâya ilişkin belirttiği faktörleri de içerecek şekilde ve duygusal zekâ modelinin dört boyutuna bağlı kalarak Chan $(2004 ; 2006)$ tarafından geliştirilmiş ölçektir. Araştırmada kullanılan iş performansı ölçeği ise Gündoğan' in (2016) “Duygusal Zekâ ve İş Performansı Arasındaki İlişkiler: Alanya Bölgesindeki Beş Yıldızlı Oteller Üzerine Bir Uygulama" isimli çalışmasından faydalanılmıştır. Ölçekte iş performansı, görev ve bağlamsal performans olarak belirlenmiştir. 


\section{Araştırma Verilerini Analizi}

Doğu ve Güneydoğu Anadolu Bölgesinde faaliyet göstermekte olan turist rehberlerinden elde edilen veriler, SPSS 20 istatistik paket programı kullanılarak analiz edilmiştir. Analizlerin ilk aşamasında büyük önem taşıyan veri setlerinin yapı geçerliği ve güvenirliliği test edilmiştir (Chiristensen vd., 2015:154). Ölçeklerin yapı geçerliliğini incelemede sıklıkla kullanılan açıklayıcı faktör analizi tekniği kullanılmıştır (Büyüköztürk vd., 2004:117). Güvenirliliği için ise Cronbach Alpha testi kullanılmıştır (Özdamar, 2004:623; Erkuş, 2009:132). Daha sonraki aşamada rehberlerin duygusal zeka düzeyleri ve iş performansları arasındaki olası ilişkiyi belirlemek için pearsonkorelasyon testi yapılmıştır. Son aşamada ise ise basit ve çoklu regresyon analizleri yapılarak elde edilen sonuçlar bulgular kısmında değerlendirilmiştir.

\section{BULGULAR}

Araştırmanın bulguları kapsamında, Doğu ve Güneydoğu Anadolu Bölgelerinde faaliyet gösteren rehberlerden elde edilen bilgilerin analiz edilmesiyle ulaşılan sonuçlar detaylı bir biçimde incelenmiştir.

\section{Ölçeklerin Geçerlilik ve Güvenilirliğine Yönelik Bulgular}

Araştırma kapsamında kullanılan ölçeklerin güvenirlilik düzeylerinin ölçülmesi amacıyla Cronbach's Alpha değerleri hesaplanmıştır. Ayrıca her iki ölçeği oluşturan ifadelerin daha önceki çalışmalarda geçerliliğin sağlanmasına karşılık, gerek yapısal anlamda gerekse anlaşılırlık düzeyinin ölçülmesi amacıyla faktör analizi gerçekleştirilmiştir. Gerçekleştirilen faktör analizler sonucu duygusal zeka ölçeğinin yapı geçerliliğii, güvenirlilik ve ifadelere katılım düzeyleri Tablo 1 'de yer verilmiştir.

Tablo 1. Duygusal Zekâ Ölçeğinin Geçerlilik, Güvenilirlik ve Aritmetik Ortalamalara İlişkin Sonuçları

\begin{tabular}{|c|c|c|c|c|c|c|}
\hline Maddeler & 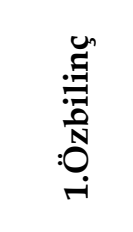 & 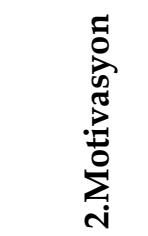 & 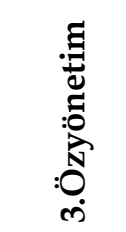 & 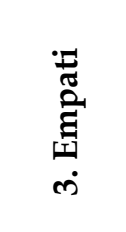 & $x$ & 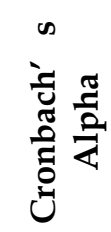 \\
\hline D1 & 894 & & & & 3,451 & \multirow{4}{*}{0,859} \\
\hline D3 & 866 & & & & 3,452 & \\
\hline \multirow[t]{2}{*}{$\mathrm{D} 2$} & ,798 & & & & 3,561 & \\
\hline & \multicolumn{4}{|c|}{ Genel Aritmetik Ortalama } & 3,473 & \\
\hline D8 & & ,862 & & & 3,167 & \multirow{4}{*}{0,841} \\
\hline D9 & & 842 & & & 3,232 & \\
\hline \multirow{2}{*}{$\mathrm{D} 7$} & &, 801 & & & 3,193 & \\
\hline & & Genel A & itmetik & ttalama & 3,197 & \\
\hline D10 & & & 866 & & 3,419 & \multirow{4}{*}{0,811} \\
\hline D11 & & & 857 & & 3,458 & \\
\hline \multirow[t]{2}{*}{ D12 } & & & 817 & & 3,535 & \\
\hline & & Genel A & itmetik & ttalama & 3,471 & \\
\hline D4 & & & & ,862 & 3,045 & \multirow{4}{*}{0,792} \\
\hline D6 & & & & 841 & 2,954 & \\
\hline \multirow[t]{2}{*}{ D5 } & & & & 777 & 3,000 & \\
\hline & & Genel A & itmetik & ttalama & 3,000 & \\
\hline Özdeğerler & 3,752 & 2,327 & 1,714 & 1,188 & \multirow{3}{*}{3,285} & \multirow{3}{*}{0,780} \\
\hline Varyans Açıklama Oranı & 31,266 & 19,390 & 14,284 & 9,900 & & \\
\hline Toplam Varyans Acıklama & ranı & 74,8 & & & & \\
\hline
\end{tabular}


Doğu ve Güneydoğu Anadolu Bölgelerinde faaliyet gösteren rehberlerden elde edilen veriler çerçevesinde, duygusal zekâ ölçeğine temel bileşenler (principalcomponents) yöntemi ve varimax rotasyonuna göre faktör analizi yapılmıştır. Rehberlerin duygusal zekâ düzeylerine ilişkin ölçeğin KMO değeri 0,758 ve Bartlett değeri $\mathrm{p}<0,000$ olarak anlamlı çıkmıştır. Bu değerlere göre; Duygusal zekâ düzeyi ölçeğinin faktör analizine uygun olduğu görülmektedir. Duygusal zekâ ölçeği toplam varyansın \%74,84'ünü açıklamaktadır. Ölçek, öz değeri $1^{\prime}$ in üzerinde olan 4 alt boyuttan oluşmakta ve faktör yükleri de 0,77-0,89 arasında değişmektedir. Dolayısıyla faktör yüklerinin 0,32 veya 0,35 ten büyük olması gerektiği düşüncesinden hareketle, duygusal zekâ ölçeği ifadelerine ilişkin faktör yüklerin de kabul edilir olduğunu söylemek mümkündür (Tabachnick ve Fidell, 2013; Büyüköztürk, 2007). Ölçeğin güvenirlik katsayısı (Cronbach's Alpha a=0,780) da kabul edilebilir düzeyde tespit edilmiştir. Bu sonucun $a=0,70$ 'in üzerinde olması, kullanılan ölçeğin oldukça güvenilir olduğunu göstermektedir (Kalaycı, 2009, s. 405).

Tablo 1'de görüldüğü üzere; birinci faktör 3 ifadeden oluşmaktadır. İç güvenirliliği 0,85, özdeğeri 3,75 ve toplam varyansın \%31,26'sını açıklayan bu faktör "Özbilinç" olarak isimlendirilmiştir. Bu boyut altında toplanan ifadelerin faktör yükleri 0,79 ile 0,89 arasında değişmektedir. İfadelerin aritmetik ortalamalarından hareketle; rehberlerin yaşarken duygularının farkında oldukları $(X=3,45)$ ve duyguların neden değişiklik gösterdiklerini bildikleri tespit edilmiştir $(X=3,56)$. Bu çerçevede engellerle karşılaşmaları durumunda, benzer engelleri daha önce yaşadıklarını ve söz konusu engellerin üstesinden geldikleri zamanları hatırlayabildikleri $(X=3,45)$ ortaya çıkmıştır. İkinci faktör 3 ifadeden oluşmaktadır. İç güvenirliliği 0,84, özdeğeri 2,32 olan ve toplam varyansın \%19,39'unu açıklayan bu faktör; genel de kişilerin umut ve motivasyonlarını ortaya ifadelerden meydana geldiği için "Motivasyon" olarak isimlendirilmiştir. Bu boyut altında toplanan ifadelerin faktör yükleri 0,80 ve 0,86 arasında çıkmıştır. Tablo 2 ' deki aritmetik ortalama sonuçları; rehberlerin engellerle karşılaştıkları durumlarda kendilerini korumak için kısmen iyi ruh hallerini kullandıkları $(X=3,23)$, üstlenmiş oldukları işin iyi sonuçlanacağını umduklarını $(X=3,16)$ ve kendilerini bu şekilde motive ettiklerini $(X=3,19)$ göstermektedir. Üçüncü faktör 3 ifadeden oluşmaktadır. İç güvenirliliği 0,81 , özdeğeri 1,71 olan ve toplam varyansın \%14,28'ini açıklayan bu faktör; genel olarak müşterileri etkilemek üzere problem çözücü ve yeni fikirler üreten kişilerin özelliklerini belirten ifadelerden meydana geldiği için "Özyönetim" olarak isimlendirilmiştir. Bu boyut altında toplanan ifadelerin faktör yükleri 0,81 ve 0,86 arasında değişmektedir. Faktör ifadelerine bakıldığında; rehberlerin olumlu ruh halindeyken yeni fikirler ürettikleri $(X=3,41)$ ve daha iyi problem çözebildikleri $(X=3,45)$ için insanlar üzerinde iyi etki bırakabildikleri $(X=3,53)$ tespit edilmiştir. Duygusal zekâ ölçeğinin dördüncü faktörü 3 ifadeden oluşmaktadır. İç güvenirliliği 0,79, özdeğeri 1,18 olan ve toplam varyansın \%9,90'ını açıklayan bu faktör; diğer insanların davranış ve mimiklerinden duygularını anlamaya yardımcı olan ifadelerden oluştuğu için "Empati" olarak isimlendirilmiştir. Bu boyut altında toplanan ifadelerin faktör yükleri 0,86 ve 0,87 arasında değişmektedir. Faktör ifadelerine bakıldığında; rehberlerin, insanların yüz ifadelerinden $(X=3,04)$, ses tonlarından $(X=3,00)$ ve gönderdikleri sözsüz mesajlardan kısmen de olsa duygularını ve neler hissedebildiklerini $(X=2,95)$ anlayabildikleri ortaya çıkmıştır. İş performansına ilişkin ölçeğin yapı geçerliliği, güvenirlilik ve ifadelere katılım düzeylerine ilişkin bulgulara Tablo 2' de yer verilmiştir.

Tablo 2. İş Performansı Ölçeğinin Geçerlilik, Güvenilirlik ve Aritmetik Ortalamalara İlişkin Sonuçları

\begin{tabular}{|c|c|c|c|c|}
\hline Maddeler & 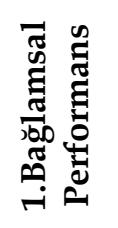 & 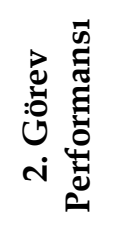 & $x$ & 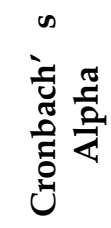 \\
\hline P9 & ,960 & & 2,941 & \multirow{4}{*}{0,986} \\
\hline $\mathrm{P} 15$ & ,958 & & 2,916 & \\
\hline $\mathrm{P} 20$ & ,952 & & 2,980 & \\
\hline $\mathrm{P} 22$ & ,951 & & 3,012 & \\
\hline
\end{tabular}




\begin{tabular}{|c|c|c|c|c|}
\hline P12 & ,947 & & 2,941 & \\
\hline P6 & ,947 & & 2,864 & \\
\hline P11 & ,944 & & 2,941 & \\
\hline P14 & ,938 & & 2,890 & \\
\hline P13 & ,928 & & 3,038 & \\
\hline P17 & ,908 & & 2,612 & \\
\hline P18 & ,908 & & 2,619 & \\
\hline P19 & 876 & & 3,122 & \\
\hline $\mathrm{P} 10$ & 865 & & 3,045 & \\
\hline P5 & 860 & & 2,716 & \\
\hline P16 & 845 & & 2,722 & \\
\hline \multirow[t]{2}{*}{$\mathrm{P} 21$} & ,773 & & 3,271 & \\
\hline & \multicolumn{2}{|c|}{ Genel Aritmetik Ortalama } & 2,751 & \\
\hline P1 & &, 847 & 2,567 & \multirow{5}{*}{0,810} \\
\hline $\mathrm{P} 4$ & & ,818 & 2,819 & \\
\hline $\mathrm{P3}$ & & ,789 & 2,903 & \\
\hline \multirow[t]{2}{*}{ P2 } & & ,729 & 2,716 & \\
\hline & \multicolumn{2}{|c|}{ Genel Aritmetik Ortalama } & 2,914 & \\
\hline Özdeğerler & 13,352 & 2,577 & \multirow{3}{*}{2,882} & \multirow{3}{*}{0,961} \\
\hline Varyans Açıklama Oranı & 66,761 & 12,884 & & \\
\hline Toplam Varyans Açıklama Oranı & \multicolumn{2}{|c|}{79,645} & & \\
\hline
\end{tabular}

Turist rehberlerinden elde edilen veriler çerçevesinde, iş performansı ölçeğine temel bileşenler (principalcomponents) yöntemi ve varimax rotasyonuna göre faktör analizi yapılmıştır. Ancak analiz sonucunda düşük yüklenme değerine (<.40) sahip ve/veya çapraz yüklenen 7 . ve 8 . ifadeler bir sonraki faktör analizine dâhil edilmemiştir. Kalan 20 ifadenin faktör analizine tabi tutulması sonucunda yüklenme değeri $0,40^{\prime}$ in ve özdeğeri 1'in üzerinde toplam varyansın yaklaşık \%79,64'ünü açıklayan 2 faktör elde edilmiştir. İş performansına ilişkin ölçeğin KMO değeri 0,955 ve Bartlett değeri $p<0,000$ olarak ortaya çıkmıştır. Bu değerlere göre; iş performansı ölçeğinin faktör analizine uygun olduğu ortaya çıkmıştır. Faktör yüklerinin 0,32 veya 0,35 'ten büyük olması gerektiği düşüncesinden hareketle, iş performansı ölçeğinin kullanılabilir olduğu söylenebilir (Tabachnick ve Fidell, 1989; Büyüköztürk, 2007). Ölçeğin güvenirlik katsayısı $(\alpha=0,961)$ da kabul edilebilir düzeyde tespit edilmiştir. Bu sonucun a=0,70'in üzerinde olması, kullanılan ölçeğin yüksek düzeyde güvenilir olduğu anlamına gelmektedir (Kalayc1, 2009:405; Hair vd., 1998:611).

Tablo 2'de görüldüğü üzere; birinci faktör16 ifadeden oluşmakta ve ifadeler dikkate alınarak "Bağlamsal Performans" olarak isimlendirilmiştir. Ölçeğin iç güvenirliliği 0,98 özdeğeri 13,35 ve varyans açılama oranı $\% 66,76^{\prime}$ dır. Bu boyut altında toplanan ifadelerin faktör yükleri 0,77 ile 0,96 arasında değişmektedir. İfadelerin aritmetik ortalamalarından hareketle; bağlamsal performans ifadelerine kısmi düzeyde katılım gösterdikleri görülmektedir $(X=2,75)$. İş performansının ikinci faktörü 4 maddeden oluşmaktadır. İç güvenirliliği 0,81, özdeğeri 2,57 olan ve toplam varyansın \%12,88'ini açıklayan bu faktör; yapılan işle ilgili mesleki bilgiyi ortaya koyan ifadeler meydana gelmektedir. Bu nedenle, ikinci faktör "Görev Performansı" olarak isimlendirilmiştir. Bu boyut altında toplanan ifadelerin faktör yükleri 0,72-0,84 arasında çıkmıştır. Tablo 3 'te görüldüğü gibi görev performansına da kısmi düzeyde bir katılım olduğu söylenebilir $(X=2,91)$.

\section{Duygusal Zekâ ve İş Performansı Arasındaki İlişki}

Araştırmanın hipotezi olan " $\mathbf{H}_{1}$ : Duygusal zekâ ve rehberlerin iş performansları arasında pozitif bir ilişki vardır"hipotezini test etmek için Pearson Korelasyon analizi yapılmıştır. Bu kapsamda duygusal zekâ ve iş performansı arasındaki ilişkiye yönelik sonuçlar Tablo 3'te gösterilmiştir. 
Tablo 3. Duygusal Zekâ ve İş Performansı İlişkisi

\begin{tabular}{|c|c|c|c|c|}
\hline \multicolumn{2}{|c|}{ Pearson Korelasyon } & \multirow{2}{*}{$\begin{array}{r}\text { İş Performans1 } \\
0,296^{* *}\end{array}$} & \multirow{2}{*}{$\begin{array}{l}\text { Bağlamsal Performans } \\
0,370^{* *}\end{array}$} & \multirow{2}{*}{$\begin{array}{l}\text { Görev Performans1 } \\
0,226^{* *}\end{array}$} \\
\hline & $\mathbf{r}$ & & & \\
\hline $\begin{array}{l}\text { Duygusal } \\
\text { Zekâ }\end{array}$ & $\mathbf{p}$ & 0,000 & 0,000 & 0,005 \\
\hline & $\mathbf{N}$ & 155 & 155 & 155 \\
\hline \multirow{3}{*}{ Özbilinç } & $\mathbf{r}$ & $0,404^{* *}$ & $0,207^{* *}$ & $0,374^{* *}$ \\
\hline & p & 0,000 & 0,010 & 0,000 \\
\hline & $\mathbf{N}$ & 155 & 155 & 155 \\
\hline \multirow{3}{*}{ Motivasyon } & $\mathbf{r}$ & $0,298^{* *}$ & $0,239^{* *}$ & $0,257^{* *}$ \\
\hline & p & 0,000 & 0,003 & 0,001 \\
\hline & $\mathbf{N}$ & 155 & 155 & 155 \\
\hline \multirow{3}{*}{ Özyönetim } & $\mathbf{r}$ & $-0,175^{*}$ & $0,159^{*}$ & $-0,217^{* *}$ \\
\hline & $\mathbf{p}$ & 0,029 & 0,048 & 0,007 \\
\hline & $\mathbf{N}$ & 155 & 155 & 155 \\
\hline \multirow{3}{*}{ Empati } & $\mathbf{r}$ & $0,218^{* *}$ & $0,325^{* *}$ & 0,155 \\
\hline & p & 0,006 & 0,000 & 0,054 \\
\hline & $\mathbf{N}$ & 155 & 155 & 155 \\
\hline
\end{tabular}

Not: ${ }^{*} \mathrm{p}<0,05 ;{ }^{* *} \mathrm{p}<0,01$

Tablo 3'teki sonuçlara göre; duygusal zekâ ile iş performansı $(r=0,296)$ arasında çok zayıf ve pozitif bir ilişki olduğu tespit edilmiştir. Bu sonuca göre $\mathbf{H}_{\mathbf{1}}$ hipotezi kabul edilmiştir. Bunun yanı sıra duygusal zekânın alt boyutu olan özbilinç ile iş performansının alt boyutu bağlamsal performans arasında $(\mathrm{r}=0,207)$ zayıf bir ilişki varken, görev performansı $(\mathrm{r}=0,374)$ ile çok zayıf bir ilişkisi olduğu belirlenmiştir. Duygusal zekânın alt boyutu olan motivasyon ile iş performansının alt boyutu bağlamsal performans $(\mathrm{r}=0,298)$ ve görev performansı $(\mathrm{r}=0,257)$ arasında zayıf bir ilişki bulunmuştur. Duygusal zekânın alt boyutu olan özyönetim ile iş performansının alt boyutu bağlamsal performans $(\mathrm{r}=-0,159)$ arasında zayıf bir ilişki varken; görev performansı $(\mathrm{r}=0,217)$ arasında pozitif ve çok zayıf bir ilişki tespit edilmiştir. Duygusal zekânın alt boyutu olan empati ile iş performansının alt boyutu bağlamsal performans $(\mathrm{r}=0,325)$ arasında zayıf bir ilişki tespit edilmiş olup $(\mathrm{p}>0,05)$, görev performansı arasında $(\mathrm{r}=0,155)$ anlamlı bir belirlenmemiştir.

\section{Duygusal Zekânın Rehberlerin İş Performansı Üzerine Etkisi}

Araştırmanın ikinci " $\mathbf{H}_{2}$ : Rehberlerin duygusal zekâsı iş performanslarını etkilemektedir" hipotezini test etmek için basit regresyon analizi yapılmıştır. Ayrıca çalışmada duygusal zeka alt boyutlarının iş performansının alt boyutlarına olan olası etkisi çoklu regresyon analizi ile belirlenmeye çalışılmıştır. Duygusal zekanın iş performansına olan etkisi Tablo 4 'te gösterilmiştir.

Tablo 4. Duygusal Zekânın Rehberlerin İş Performansları Üzerine Etkisi

\begin{tabular}{|c|c|c|c|c|c|}
\hline \multirow[t]{2}{*}{ Model } & \multicolumn{2}{|c|}{$\begin{array}{c}\text { Standartlaştırılmamış } \\
\text { Katsayılar }\end{array}$} & \multirow{2}{*}{$\begin{array}{c}\begin{array}{c}\text { Standartlaştırılmış } \\
\text { Katsayılar }\end{array} \\
\text { Beta }\end{array}$} & \multirow[t]{2}{*}{$\mathrm{t}$} & \multirow{2}{*}{$\mathrm{p}$} \\
\hline & $\mathrm{B}$ & Std. Hata & & & \\
\hline Sabit & 1,418 & 0,390 & & 3,634 & $0,000^{*}$ \\
\hline Duygusal Zekâ & 0,446 & 0,116 & 0,296 & 3,832 & $0,000^{*}$ \\
\hline \multicolumn{2}{|c|}{$\mathrm{R}$} & \multicolumn{2}{|r|}{0,296} & & \\
\hline \multicolumn{2}{|c|}{$\mathrm{R}^{2}$} & \multicolumn{2}{|r|}{0,088} & & \\
\hline \multicolumn{2}{|c|}{ Düzeltilmiş $\mathrm{R}^{2}$} & \multicolumn{2}{|r|}{0,082} & & \\
\hline \multicolumn{2}{|c|}{ Standart Hata } & \multicolumn{2}{|r|}{0,989} & & \\
\hline \multicolumn{2}{|c|}{$\mathrm{F}$} & \multicolumn{2}{|r|}{14,688} & & $0,000^{*}$ \\
\hline
\end{tabular}


Tablo 4'teki sonuçlar; duygusal zekâ ile ilgili düzeltilmiş determinasyon katsayısının \%8,2 olduğunu göstermektedir. Bu sonuca göre, iş performansındaki değişimin \%8,2'si, duygusal zekâ düzeyinde meydana gelen değişime bağlıdır. Modelin 14,688 oranında $F$ değeri aldığı ve $p$ değerinin de anlamlı olduğu görülmektedir. Modelin bağımsız değişkeni olan duygusal zekânın katsayısı 0,446, $t$ değeri 3,832 ve anlamlılık düzeyi $p<0,05$ oranında çıkmıştır. Bu sonuca göre; duygusal zekâ, iş performansını 0,446 birim etkilemektedir. Bu sonuca göre $\mathbf{H}_{2}$ hipotezi kabul edilmiştir. Duygusal zekâ alt boyutlarının, rehberlerin bağlamsal performansları üzerindeki etkisini belirlemek için yapılan Çoklu Regresyon analizi sonuçları Tablo 5 'te sunulmuştur.

Tablo 5. Duygusal Zekâ Alt Boyutlarının Rehberlerin Bağlamsal Performansları Üzerine Etkisi

\begin{tabular}{|c|c|c|c|c|c|}
\hline \multirow[t]{2}{*}{ Model } & \multicolumn{2}{|c|}{$\begin{array}{c}\text { Standartlaştırılmamış } \\
\text { Katsayılar }\end{array}$} & \multirow{2}{*}{$\begin{array}{c}\begin{array}{c}\text { Standartlaştırılmış } \\
\text { Katsayılar }\end{array} \\
\text { Beta }\end{array}$} & \multirow[t]{2}{*}{$t$} & \multirow[t]{2}{*}{$\mathrm{p}$} \\
\hline & $\mathrm{B}$ & Std. Hata & & & \\
\hline Sabit & 1,903 & 0,469 & & 4,054 & $0,000^{*}$ \\
\hline Özbilinç & 0,333 & 0,099 & 0,278 & 3,350 & $0,001^{*}$ \\
\hline Motivasyon & 0,154 & 0,090 & 0,144 & 1,705 & 0,090 \\
\hline Özdenetim & $-0,267$ & 0,086 & $-0,232$ & $-3,097$ & 0,002 \\
\hline Empati & 0,097 & 0,087 & 0,085 & 1,108 & 0,270 \\
\hline \multicolumn{2}{|c|}{$\mathrm{R}$} & \multicolumn{2}{|r|}{0,452} & & \\
\hline \multicolumn{2}{|c|}{$\mathrm{R}^{2}$} & \multicolumn{2}{|r|}{0,204} & & \\
\hline \multicolumn{2}{|c|}{ Düzeltilmiş $\mathrm{R}^{2}$} & \multicolumn{2}{|r|}{0,183} & & \\
\hline \multicolumn{2}{|c|}{ Standart Hata } & \multicolumn{2}{|r|}{1,023} & & \\
\hline \multicolumn{2}{|c|}{$\mathrm{F}$} & \multicolumn{2}{|r|}{9,624} & & $0,000^{*}$ \\
\hline
\end{tabular}

Tablo 5'teki sonuçlar; duygusal zekâ alt boyutlarına ilişkin düzeltilmiş determinasyon katsayısının \%18,3 olduğunu göstermektedir. Bu sonuca göre, bağlamsal performansta yaşanan değissimin \%18,3'ü, duygusal zekâ alt boyutlarında meydana gelen değişime bağlıdır. Modelin 9,624 oranında $\mathrm{F}$ değeri aldığı ve p değerinin de anlamlı çıktığı görülmektedir. Modelde anlamlı sonuçlar veren bağımsız değişkenlerden özbilinç boyutunun katsayısı 0,333 ve özdenetim boyutunun katsayısı -0,267 olarak tespit edilmiştir. Bu çerçevede; öz bilinçlerini kullanım düzeyleri bağlamsal performanslarını 0,333 birim arttırırken; özdenetimi sağlamaları bağlamsal performanslarını -0,267 birim düşürmektedir.

Duygusal zekâ alt boyutlarının, rehberlerin görev performansları üzerindeki etkisini belirlemek için yapılan Çoklu Regresyon analizi sonuçları Tablo 6'da sunulmuştur.

Tablo 6. Duygusal Zekâ Alt Boyutlarının Rehberlerin Görev Performansları Üzerine Etkisi

\begin{tabular}{|c|c|c|c|c|c|}
\hline \multirow[t]{2}{*}{ Model } & \multicolumn{2}{|c|}{$\begin{array}{c}\text { Standartlaştırılmamış } \\
\text { Katsayılar } \\
\end{array}$} & \multirow{2}{*}{$\begin{array}{c}\begin{array}{c}\text { Standartlaştırılmış } \\
\text { Katsayılar }\end{array} \\
\text { Beta }\end{array}$} & \multirow[t]{2}{*}{$t$} & \multirow[t]{2}{*}{$\mathrm{p}$} \\
\hline & $\mathrm{B}$ & Std. Hata & & & \\
\hline Sabit & 0,832 & 0,426 & & 1,955 & $0,050^{*}$ \\
\hline Özbilinç & 0,120 & 0,090 & 0,114 & 1,332 & 0,185 \\
\hline Motivasyon & 0,094 & 0,082 & 0,100 & 1,145 & 0,254 \\
\hline Özdenetim & 0,122 & 0,078 & 0,120 & 1,558 & 0,121 \\
\hline Empati & 0,260 & 0,079 & 0,259 & 3,271 & $0,001^{*}$ \\
\hline \multicolumn{2}{|c|}{$\mathrm{R}$} & \multicolumn{2}{|r|}{0,388} & & \\
\hline \multicolumn{2}{|c|}{$\mathrm{R}^{2}$} & \multicolumn{2}{|r|}{0,151} & & \\
\hline \multicolumn{2}{|c|}{ Düzeltilmiş $\mathrm{R}^{2}$} & \multicolumn{2}{|r|}{0,128} & & \\
\hline \multicolumn{2}{|c|}{ Standart Hata } & \multicolumn{2}{|r|}{1,019} & & \\
\hline \multicolumn{2}{|c|}{$F$} & \multicolumn{2}{|r|}{6,647} & & $0,000^{*}$ \\
\hline
\end{tabular}


Tablo 6'daki sonuçlar; duygusal zekâ alt boyutlarına ilişkin düzeltilmiş determinasyon katsayısının \%12,8 olduğunu göstermektedir. Bu sonuca göre, görev performansında yaşanan değişimin \%12,8'i, duygusal zekâ alt boyutlarında meydana gelen değişime bağlıdır. Modelin 6,647 oranında F değeri aldığı ve p değerinin de anlamlı çıtığı görülmektedir. Modelde anlamlı sonuçlar veren bağımsız değişkenlerden empati boyutunun katsayısı 0,260 olarak tespit edilmiştir. $\mathrm{Bu}$ çerçevede; rehberlerin empati kurma düzeyleri görev performanslarını 0,260 birim arttırmaktadır.

\section{SONUÇ VE ÖNERİLER}

Doğu ve Güneydoğu Anadolu bölgesinde faaliyet gösteren rehberlerden elde edilen veriler sonucunda rehberlerin yaşarken duygularının farkında oldukları ve duyguların neden değişiklik gösterdiklerini bildikleri tespit edilmiştir. Bu çerçevede engellerle karşılaşmaları durumunda, benzer engelleri daha önce yaşadıklarını ve söz konusu engellerin üstesinden geldikleri zamanları hatırlayabildikleri ortaya çıkmıştır. Rehberlerin engellerle karşılaştıkları durumlarda kendilerini korumak için kısmen iyi ruh hallerini kullandıkları, üstlenmiş oldukları işin iyi sonuçlanacağını umdukları ve kendilerini bu şekilde motive ettikleri belirlenmiştir. Rehberlerin olumlu ruh halindeyken yeni fikirler ürettikleri ve daha iyi problem çözebildikleri için insanlar üzerinde iyi etki bırakabildikleri tespit edilmiştir. Rehberlerin, insanların yüz ifadelerinden, ses tonlarından ve gönderdikleri sözsüz mesajlardan kısmen de olsa duygularını ve neler hissedebildiklerini anlayabildikleri ortaya çıkmıştır.

Turizm sektöründe önemli bir yere sahip olan turist rehberleri, başarılı olabilmek için yoğun emek harcamaktadırlar, başarının kalıcı olması için daha donanımlı olmak durumundadırlar. Bu başarıyı yüksek derecede duygusal zeka sayesinde sağlayabilirler. Blackwelder (2018:10)'e göre duygusal zeka yüksek olunca daha öz güvenli ve rahat hissedilmektedir. Duygusal zekalarınıgeliştirip ya da ilerletilerek tecrübeli olanlar ya da meslekte yeni olanlar müşterileriyle ve ilişkide olmaları gereken kişilerle daha iyi iletişim kurabilmekte aynı zamanda iyi rehberlik edebilmektedirler. Turist rehberlerinin başarısının bağlı olduğu; güven, merak, amaç gütme, ilişki kurabilme, iletişim yeteneği ve iş birliği yapabilme gibi; anahtar öğeler duygusal zeka ile ilgili yeteneklerdir. Turist rehberlerinin bu yeteneklerle donanmış olup olmadıkları, Goleman (2014:257)'nın ifade etmiş olduğu gibi eğitime somut kavramlarla başlamak yerine kalpten başlamaya bağlıdır. Burada vurgulanmak istenen şey; özel hayatta ve iş yaşamında başarılı olmak için akademik alanda eğitimli olmaktan ziyade duygusal yeterliliğin daha hayati olduğudur. Nitekim İştahlı'nın (2013:45) belirttiği gibi, duygusal zeka iş başında bir performans kriteri olarak ele alınmak durumundadır. Yüksek duygusal zekaya sahip çalışanın pozitif düşüncelerini yüksek performansa çevirerek bunun sonucunda başarı ve kazanç sağlayabilecekleri düşünülmektedir.

Araştırmanın alan çalışması sonuçlarına göre turist rehberlerinin yüksek duygusal zekaya sahip oldukları ancak duygusal zeka ile iş performansları arasında anlamlı ve düşük ilişki olduğu saptanmıştır. Ancak rehberlerin bağlamsal performans ve görev performansına ilişkin ifadelere orta düzeyde katılım gösterdikleri görülmüştür. Duygusal zeka boyutlarıyla iş performans boyutları arasında pozitif yönlü ve zayıf ilişki olduğu saptanmıştır. Dolayısıyla ileriki araştırmalar için duygusal zekanın iş performansına etkisinin daha büyük örneklem grubu ile ele alınması önerilmektedir. Araştırma evreni ve süre sınırlılıklarının araştırma verilerinin sonuçları üzerinde etkili olduğu düşünülerek daha geniş kitleye ulaşılarak yüksek ilişkinin saptanacağı ileri sürülmektedir. Turizm sektörünün çeşitli alanlarında duygusal zekanın varlığının ve öneminin ele alınması, duygusal zekanın turizm sektörünün diğer konuları ile ilişkisinin araştırılması ile literatüre katkı sağlanması önerilmektedir. Bunun yanı sıra turizm sektöründe iş performansını etkileyen en önemli unsurların saptanması için ayrıca bir araştırma yapılması önemli ve etkin sonuçlar ortaya koyacaktır. Turizmde karar ve yetki sahibi yöneticiler ve pazarlamacıların iş performansını yükselten ve düşüren noktalara dikkat ederek daha iyi iş gücü yaratabilirler. Ayrıca duygusal zekası yüksek çalışanlarla olmanın başarıyı sağlayacağı dikkate alınmalıdır. 


\section{Kaynakça}

Acar, F. T. (2002). Duygusal Zeka Ve Liderlik, Sosyal Bilimler Enstitüsü Dergisi. 12, 53-68.

Arıkan, R. (2005) Araştırma Teknikleri ve Rapor Hazırlama, Ankara: Asil Yayın.

Aslan, Ş. (2013). Duygusal Zeka Dönüşümcü ve Etkileşimci Liderlik. (2). Eğitim Yayınevi. Konya.

Avunduk, Y. (2016). Duygusal Zekânın İş Performansı Üzerindeki Etkisi: Tıp Doktorları İle Toplu Ulaşım Şoförleri Üzerinde Karşılaştırmalı Alan Uygulaması, Doktora Tezi, İstanbul Ticaret Üniversitesi Sosyal Bilimler Enstitüsü, İstanbul.

Ayana, Ç. (2016). Duygusal Zekânın Örgütsel Sinizme Etkisi: Otel İşletmeleri İş görenleri Üzerinde Bir Araştırma, İşletme Araştırmaları Dergisi, 8, 2, 45-76.

Bal, S. (2007). Takım Çalışmasında Duygusal Zekanın Önemi, Yüksek Lisans Tezi, Beykent Üniversitesi Sosyal Bilimler Enstitüsü, İstanbul.

Bar-On, R. (2006). The Bar-On Model Of Emotional-Social İntelligence (ESI), Psicothema, 18, 13-25.

Baş, T. (2010) Anket, Ankara: Seçkin Yayıncılık ve San. ve Tic. Aş.

Blackwelder J. (2018). Improving Our Emotional Intellıgence, AJN, 118(1), 10.

Büyüköztürk, Ş.(2007) Sosyal Bilimler İçin Veri Analizi El Kitabı, Ankara: Pegem Yayıncılık.

Büyüköztürk, Ş., Akgün, Ö. E., Özkahveci, Ö. ve Demirel, F. (2004) “Güdülenme ve Öğrenme Stratejileri Ölçeğinin Türkçe Formunun Geçerlilik ve Güvenirlik Çalışması", Kuram ve Uygulamada Ĕ̆itim Bilimleri, 4 (2), 207-239.

Büyüköztürk, Ş., Çakmak, E. K., Akgün, Ö. E., Karadeniz, Ş. ve Demirel, F. (2010) Bilimsel Araştırma Yöntemleri, Ankara: Pegem Akademi.

Castillo M.,Valle I. (2017). "Is emotional intelligence the panacea for a better job performance? A study on low-skilled back Office jobs", Employee Relations, Vol. 39(5), 683-698.

Chiristensen, B. L., Johnson, R. B. Turner, L. A. (2015) Research Methods, Design and Analysis, Twelfth Edition, England: Pearson Education Limited.

Çakar, U., veArbak, Y. (2004).Modern yaklaşımlar ışığında değişen duygu zekâ ilişkisi ve duygusal zekâ,Dokuz Eylül Üniversitesi Sosyal Bilimler Enstitüsü Dergisi, 6, 3, 23-48.

Çakar, U., Arbak, Y. (2016). Dönüşümcü Liderlik Duygusal Zekâ Gerektirir Mi? Yöneticiler Üzerinde Örnek Bir Çalışma, Dokuz Eylül Üniversitesi İktisadi İdari Bilimler Fakültesi Dergisi, 18 (2), 83-98.

Davis, M. (2004). Duygusal Zekanızı Ölçün. (1). İstanbul: Melisa.

Doğan, H. (2014). Örgütsel Adalet Algısı İle İş Performansı Arasındaki İlişki: Afyonkarahisar'da Beş Yıldızh Termal Otel İşletmelerinde Bir Araştırma, Yüksek Lisans Tezi, Afyon Kocatepe Üniversitesi Sosyal Bilimler Enstitüsü, Afyonkarahisar.

Dong, Y.,Seo, M., Bartol, K.. (2014). No Pain, No Gain: An Affect-Based Model Of Developmental Job Experience And The Buffering Effects Of Emotional Intelligence, Academy of Management Journal, 57(4), 1056-1077.

Ebrahimi L., vd. (2017). ComparingtheQuality of Life and Emotional Intelligence among Patients with Psychosomatic Disease (Type 2 Diabetes) and Healthy Individuals, Neuro Quantology, 15(3), 12-19.

Emelander, S. (2013). On the Job With Emotional Intelligence, Defense ATEL, 4, 5, 57.

Erkuş, A. (2009) Davranış Bilimleri İçin Bilimsel Araştırma Süreci, Ankara: Seçkin Yayıncılık.

Ernest, J. R. vd.(2011). The Relation Between Emotional İntelligence And Job Performance: A Meta-Analysis, Journal of Organizational Behavior, 32, 788-818. 
Ertan, H. (2008). Örgütsel Bağ̆lılık, İş Motivasyonu ve İş Performansı Arasındaki İlişki: Antalya'da Beş Yıldızlı Otel İşletmelerinde Bir İnceleme, Doktora Tezi, Afyonkarahisar Kocatepe Üniversitesi Sosyal Bilimler Enstitüsü, Afyonkarahisar.

Genç, V. (2013). Alanya'daki Turizm İşletmelerinde Çalışanların Duygusal Emek ve Duygusal Zeka Düzeylerinin İş Tatminine Etkileri, Yüksek Lisans Tezi, Çanakkale On sekiz Mart Üniversitesi Sosyal Bilimler Enstitüsü, Çanakkale.

Goleman, D. (2000). İş Başında Duygusal Zeka. (2). İstanbul: Varlık.

Goleman, D. (2014). Duygusal Zeka Neden EQ'dan Daha Önemlidir? (39). İstanbul: Varlık.

Gökgöz, S. (2016). Lider Üye Etkileşiminin Algılanan İş Performansına Etkisinde Örgütsel Vatandaşlık Davranışını Rolü, Yüksek Lisans Tezi, Türk Hava Kurumu Üniversitesi Sosyal Bilimler Enstitüsü, İstanbul.

Gürbüz, S. ve Yüksel, M. (2008). Çalışma Ortamında Duygusal Zeka: İş Performansı, İş Tatmini, Örgütsel Vatandaşlık Davranışı ve Bazı Demografik Özelliklerle İlişkisi, Doğuş Üniversitesi Dergisi, 9 (2), 174-190.

Gürsoy, A. (2005). Liderlikte Duygusal Zeka (Liderlik İle Duygusal Zekalı Lidere Ulaşılması) Türk Silahl Kuvvetlerinde Örnek Bir Uygulama, Yüksek Lisans Tezi, Celal Bayar Üniversitesi Sosyal Bilimler Enstitüsü, Manisa.

Hair, J. F.,Anderson, R. E., Tatham, R. L. and Black, W. C. (1998). Multivariate data analysis, 5th Edition, New Jersey: Prentice-HallInc.

Huggins K., White D., Stahl J. (2016). Antecedents To Sales Force Job Motivation And Performance: The Critical Role Of Emotional Intelligence And Affect-Based Trust In Retailing Managers, International Journal of Sales, Retailingand Marketing, 5(1), 28- 37.

İştahlı, B., ve diğerleri (2014) Kötü Niyetli Yönetim Algılamasının Çalışanların Performansları Üzerindeki Etkisinde Duygusal Zekânın Rolü, Çankırı Karatekin Üniversitesi İBF Dergisi, 4, 118.

Kalaycı, Ş. (2009). SPSS Uygulamalı Çok Değişkenli İstatistik Teknikleri, 5. Baskı, Ankara: Asil Yayın Dağıtım.

Kara, A. (2015). Kurum Kültürünün Oluşturulmasında Duygusal Zekânın Önemi ve Çalışanların İş Performansına Etkisi, Yüksek Lisans Tezi, İstanbul Ticaret Üniversitesi Sosyal Bilimler Enstitüsü, İstanbul.

Karasar, N. (2008) Bilimsel Araştırma Yöntemi, Ankara: Nobel Yayın Dağıtım.

Karayel, M. (2016). Örgütsel Destek, Lider Desteği ve Sosyal Desteğin İş Performansına Etkisinde LiderÜye Etkileşiminin Aracılı Rolü: Yerel Yönetimler Örneği, Yüksek Lisans Tezi, Türk Hava Kurumu Üniversitesi Sosyal Bilimler Enstitüsü, İstanbul.

Karmyshakova, K. (2006). Ekip Çalışmasında Liderin Duygusal Zekasının Önemi ve Bir Uygulama, Yüksek Lisans Tezi, İstanbul Üniversitesi Sosyal Bilimler Enstitüsü. İstanbul.

Kılıç, K.,Tavacıoğlu, L. (2016). Influence Of Emotıonal Intelliegence On The Work Performance Of Seafarers, Constanta Maritime University Annals, 24, 213- 222.

Kulualp, G., Erol, S. (2015). Mikro Açıdan Turizm Sektörü Yöneticilerinin Duygusal Zeka Düzeylerini Etkileyen Demografik Değişkenler, Uluslararası Yönetim İktisat ve İşletme Dergisi, (17), 120-132.

Kurt, E. (2013). Enstitüsü Algılanan Sosyal Destek ve İş Performansı İlişkisinde İşe Bağhllı̆̆ın Aracı Etkisi: Turizm İşletmelerinde Bir Araştırma, Yüksek Lisans Tezi, Hacettepe Üniversitesi Sosyal Bilimler Enstitüsü, Ankara. 
Lindebaum, D. (2013). Does Emotional İntelligence Moderate The Relationship Between Mental Health And Job Performance? An Exploratory Study, European Management Journal, 31, 538548.

Majeski, R. A.,Stover, M., Valais, T., Ronch, J. (2017). Fostering Emotional Intelligence in Online Higher Education Courses, Adult Learning, 28(4), 135-145.

Malhotra, N, Kaur, R. (2018). Study Of Emotional Intelligence In Association With Subjective Well- Being Among, Indian Journal Of Health And Well- Being, 9(1), 122- 124.

Mayer, J. D.,Perkins, D. M., Caruso, D.R., Salovey, P. (2001). Emotional Intelligence and Giftedness, Roeper Review, 23(3), 131-138.

Mayer, J.,Caruso, D., Salovey, P. (2000). Emotional Intelligence Meets Traditional Standarts for an Intelligence, Intelligence, 27 (4), 267-298.

Mayer, J.,Caruso, D., Salovey, P. (2004). Emotional Intelligence: Theory, Findings and Implications, PsychlogicalInquiry, 15 (3), 197- 215.

Mayer, J., ve diğ. (2003). Measuring Emotional Intelligence With the MSCEIT V2.0, Emotion, 3 (1), 97-105.

Mayer, J., ve diğ. (2008). Emotional Intelligence New Ability or Eclectic Traits?, American Psychological Association, 63 (6), 503-517.

Mayer, J.D., ve diğ. (2003). Measuring Emotional Intelligence With the MSCEIT V2.0, American Psychological Association, 3(1), 97-105.

Meriçöz, S. (2015). Çalışanların Örgütsel Adalet Algılarmın İş Tatminine Ve İş Performansına Olan Etkisi: Ampirik Bir Çalışma, Yüksek Lisans Tezi, Bahçeşehir Üniversitesi Sosyal Bilimler Enstitüsü, İstanbul.

Moon, T., Hur, W. (2011). Emotional Intelligence, Emotional Exhaustion, And Job Performance, Social Behavior And Personality, 39(8), 1087-1096.

Muchal, D., Solkhe, A. (2017). An Empirical Investigation Of Relationship Between Emotional Intelligence And Job Performance In Indian Manufacturing Sector, International Journal Of Research In Commerce \& Management, 8(7), 18- 23.

Nakip, M. (2013) Pazarlama Araştırma Teknikleri, 3. Baskı, Ankara: Seçkin Yayıncılık.

Önder, M. (2010). Liderlerde Duygusal Zeka ve Motivasyon İlişkisi ve Bir Uygulama, Yüksek Lisans Tezi, Gazi Üniversitesi Sosyal Bilimler Enstitüsü, Ankara.

Özcan, M., Geçici, E., Günlük, M. (2016). Muhasebecilerin Duygusal Zeka Düzeylerinin Örgütsel Bağll1ıkları Üzerindeki Etkisi, 16(2), 287-302.

Özdamar, K. (2004) Paket Programlar ile İstatistiksel Veri Analizi-I, Genişletilmiş 5. Bask1, Eskişehir: Kaan Kitabevi.

Pandey, N.,Sharma, M K.. (2016). The Impact of Emotional Intelligence on Job Satisfaction: Evidence from a Large Indian Bank, The IUP Journal of Soft Skills, 10(3), 7-23.

Pehlivan, Ş. (2015). Duygusal Zekanın (EI) Satış Elemanlarının Algıladıklan Satış Performansına Etkisi, Yüksek Lisans Tezi, Aydın Adnan Menderes Üniversitesi Sosyal Bilimler Enstitüsü, Aydın.

Ryan, C. (1995) Researching Tourist Satisfaction Issues, Concepts, Problems, London: Routledge.

Salovey, P. Ve diğ. (2006). Evidence That Emotional İntelligence İs Related To Job Performance And Affect And Attitudes At Work, Psicothema, 18, 132-138.

Salovey, P.,Caruso, D. R., Mayer, J. D. (2008). Emotional Intelligence New Ability or Eclectic Traits?, American Psychologist, 63(6), 503-517. 
Sarangi, D., vd. (2017). Emotional Intelligence, Organizational Role Stress And Job Satisfaction: Perspectives From Indian Public And Private Sector Organizations, Indian Journal Of Positive Psychology, 8(4), 478- 483.

Sekaran, U. (2003) Research Methodsfor Business, Fourth Edition, John Wiley\&Sons İnc.

Sevim, Ü. (2105). Örgütlerde Mobingin İş Performansına Etkisinde İş Aile Yaşam Çatışmasının Aracılık Rolü: Eğitim Sektöründe Bir Uygulama, Yüksek Lisans Tezi, Türk Hava Kurumu Üniversitesi Sosyal Bilimler Enstitüsü, İstanbul.

Singh, J.,Mahmood, N. (2017). Emotional Intelligence and Expatriate Job Performance in the ICT Sector: The Mediating Role of Cultural Adjustment, Global Business and Management Research: An International Journal, 9(1), 230- 245.

Sony, M.,Mekoth, N. (2016). The Relationship Between Emotional İntelligence, Front line Employee Adaptability, Job satisfaction And Job Performance, Journal of Retailingand Consumer Services, 30, 20-32.

Şahin, N.H., Güler, M. ve Basım, H.N. (2009) A Tipi Kişilik Örüntüsünde Bilişsel Ve Duygusal Zekânın Stresle Başa Çıkma Ve Stres Belirtileri İle İlişkisi,Türk Psikiyatri Dergisi, 20, 243-254.

Tabachnick, B. G. ve Fidel, L. S. (2013). Using multivariate Statistics. USA: Pearson Education Limited

Tabachnick, B. G. ve Fidell, L. S. (1989) Using Multivariate Statistics, Second Education, Northridge: California State University Publish.

Ulus, T., İnce, C. H., Aliustaoğlu, F. S. ve Melez, İ. E. (2010) “Araştırma Nasıl Tasarlanır (I)”, Adli Tip Dergisi, 24 (2), 40-47.

Yalçın, K. (2017). Duygusal Zekânın İş Performansına Etkileri: Ankara Pursaklar İlçesindeki Otomotiv Yetkili Bayileri Üzerinde Bir Araştırma, Yüksek Lisans Tezi, Türk Hava Kurumu Üniversitesi Sosyal Bilimler Enstitüsü, İstanbul.

Yamane, T. (2001) Temel Örnekleme Yöntemleri, Çev. A. Esin, M. A. Bakır, C. Aydın ve E. Gürbüzsel. İstanbul: Literatür Yayıncılık.

Yöney, H. (2001). Emotional Intelligence, Marmara Medical Journal, 14(1 ), 47 -52. 